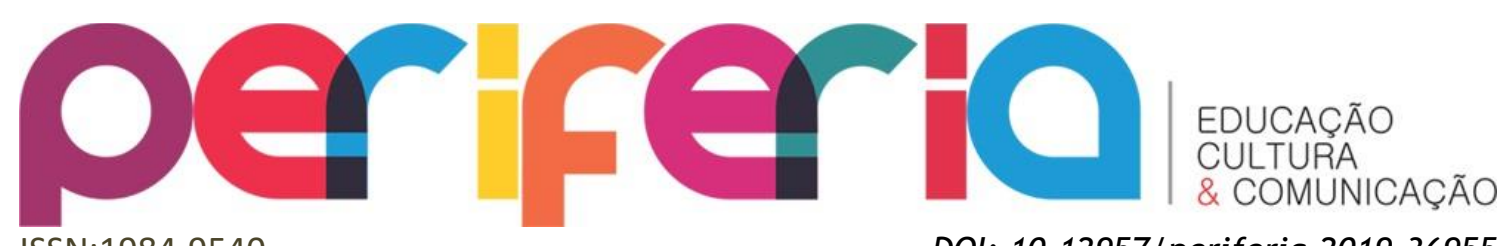

ISSN:1984-9540

DOI: 10.12957/periferia.2019.36955

\title{
MULTIMODALIDADE E EFEITOS DE SENTIDO NO GÊNERO MEME
}

\author{
Josiane Brunetti Cani ${ }^{1}$ \\ Universidade Federal de Minas Gerais - UFMG
}

\section{Resumo}

Considerando a importância de compreender a natureza constitutiva dos gêneros influenciada pelos recursos tecnológicos digitais, este trabalho tem como objetivo discutir a multimodalidade presente no gênero meme. A partir de uma análise multimodal à luz dos pressupostos teóricos abordados por Jewitt e Hiippala, apresentam-se alguns memes coletados no Facebook, estabelecendo uma taxonomia desses autores para a análise da multimodalidade relacionada aos principais usos desse gênero como dinâmica social. Utiliza-se uma abordagem qualitativa, abrangendo aspectos da linguagem visual e verbal, bem como elementos interativos de comunicação social. A análise permitiu concluir que as representações semióticas desses textos, facilmente replicáveis, seja por meio de crítica, humor ou carga emocional, promovem impactos nas práticas sociais.

Palavras-chave: multimodalidade; gêneros; memes; práticas sociais

\footnotetext{
${ }^{1}$ Doutoranda em Linguística Aplicada pela UFMG, Mestre em Educação, possui graduação em Letras pela Faculdade de Filosofia, Ciências e Letras de Colatina, com pós-graduação em Planejamento Educacional e em Gestão Integradora: Supervisão Escolar, Orientação Escolar e Inspeção Escolar. Atualmente, exerce a função de Técnico em Assuntos Educacionais do Instituto Federal de Educação, Ciência e Tecnologia do Espírito Santo. E-mail: josicani@gmail.com
} 


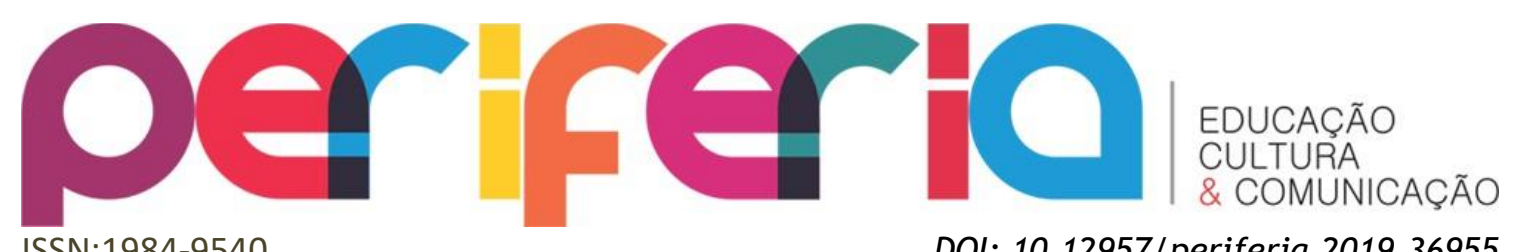

\title{
MULTIMODALITY AND EFFECTS OF SENSE IN THE GENDER MEME
}

\begin{abstract}
Considering the importance of understanding the constitutive nature of the genres and the imbrications with the social and cultural context, influenced by the digital technological resources, this work aims to discuss the multimodality present in the meme genre. From a multimodal analysis in the light of the theoretical assumptions mentioned by Jewitt (2013) and Hiippala (2014), we will present some memes collected on Facebook, establishing a taxonomy of these authors for the analysis of multimodality related to the main uses of this genre as social dynamics. A qualitative approach was used, covering aspects of both visual and verbal language, as well as interactive elements of social communications. The analysis allowed us to conclude that the semiotic representations of these texts, easily replicated, whether through criticism, humor or emotional load, promote impacts on social practices.
\end{abstract}

Keywords: multimodality; genres; memes; social practices 


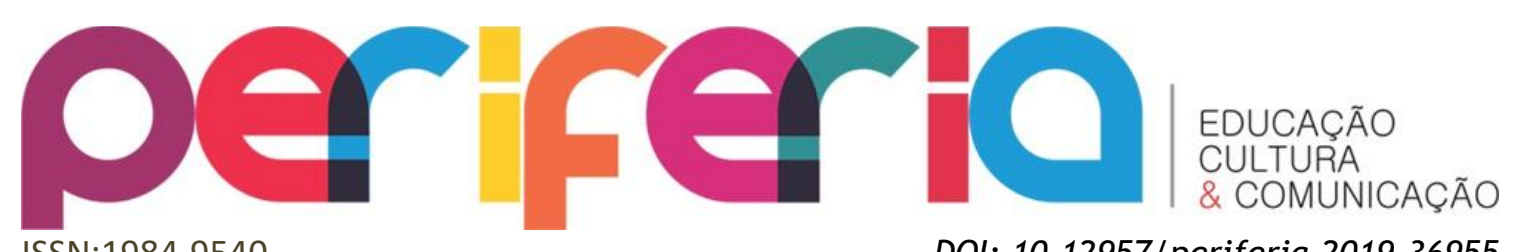

ISSN:1984-9540

DOI: 10.12957/periferia.2019.36955

\section{MULTIMODALIDAD Y EFECTOS DE SENTIDO EN EL GÉNERO MEME}

\section{Resumen}

Ante la importancia de comprender la naturaleza constitutiva de los géneros y sus constituciones influenciadas por los recursos tecnológicos digitales, este trabajo objetiva discutir la multimodalidad presente en el género meme. A partir de un análisis multimodal a la luz de los presupuestos teóricos enumerados por Jewitt (2013) e Hiippala (2014), presentaremos algunos memes recogidos en Facebook, estableciendo una taxonomía de esos autores para el análisis de la multimodalidad relacionada a los principales usos de ese género como dinámica social. Se utilizó un abordaje cualitativo, abarcando aspectos tanto del lenguaje visual y de la verbal, además de elementos interactivos de las comunicaciones sociales. El análisis permitió concluir que las representaciones semióticas de esos textos, fácilmente replicados, sea por la crítica, el humor o la carga emocional, promueven impactos en las prácticas sociales.

Palabras clave: multimodalidad; géneros; memes; prácticas sociales 


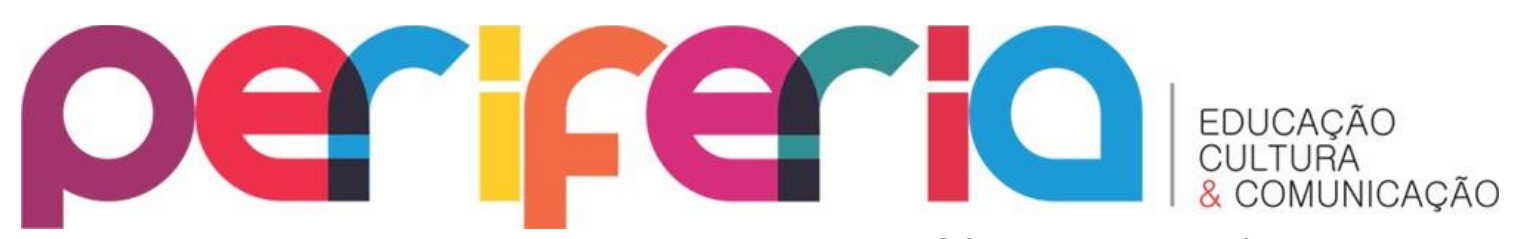

ISSN:1984-9540

DOI: $10.12957 /$ periferia.2019.36955

\section{INTRODUÇÃO}

A noção de gênero, ao longo do tempo, tem sido assunto para inúmeros campos do saber a partir da filosofia clássica. Do latim genus, no século VI a.C., seu sentido já se apresentava associado à classificação, como na doutrina de Platão que, ao envolver a realidade, estabeleceu uma divisão do mundo entre o gênero das formas e o das ideias (BREURE, 2001). Aristóteles (1988), por sua vez, propôs a organização da oratória em três gêneros: o forense, no qual o orador acusa ou defende; o deliberativo, com a intenção de aconselhar ou dissuadir o auditório; e o epidítico, um discurso usado para elogios ou repreensão a uma pessoa. Trazemos, dessa abordagem dos gêneros, que remontam da Antiguidade, as práticas comunicativas que surgem por meio das tecnologias digitais.

Presenciamos o desenrolar dos estudos sobre gêneros por inúmeras perspectivas que discutem suas origens (TODOROV, 1976), bem como suas abordagens teóricas sociossemióticas (HASAN, 1994; KRESS, 1985; FAIRCLOUGH, 1992), sócioretóricas (SWALES, 1992; MILLER, 1994; BAZERMAN, 2005) ou sociodiscursivas (BAKHTIN, 1992; ADAM, 1999; BRONCKART, 1999). Muitas pesquisas vêm se materializando com intenção de proporcionar ao gênero um lugar de destaque no ensino de línguas, ressaltando principalmente seu papel na situação interacional e de cultura. Nesse sentido, necessitamos reconhecer que, com o advento das novas tecnologias digitais, a materialização dos textos se ampliou significativamente, com destaque para as transformações geradas pela internet, não só nos modos de veiculação e circulação dos gêneros, mas também em sua estrutura.

Além da dinamicidade proposta por essa rede de computadores, celulares e smartphones, os domínios digitais intensificaram as propostas textuais por meio de imagens, cores, sons e vídeos - movimentos pela estruturação cada vez mais multimodal dos textos contemporâneos. Tal multimodalidade tem conduzido à construção de gêneros que se moldam ao ambiente virtual, especialmente nas redes sociais, e um deles nos chama a atenção: os memes. Com estratégias diferenciadas, aplicamos na oratória desse gênero três situações que podem relacionar a proposta de Aristóteles (1988) à contemporaneidade: (1) o forense - abordagens de acusação e defesa para notícias políticas, econômicas ou sociais; (2) o deliberativo 


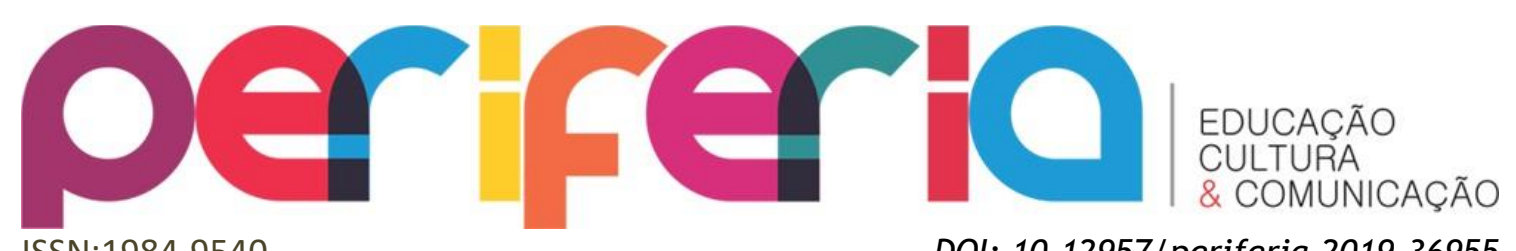

ISSN:1984-9540

argumentos de manobras políticas e de oferta de serviços; e (3) o epidítico - discursos de elogios, censura ou repreensão de atitudes para pessoas públicas e/ou famosas. Assim, este trabalho se firma na atualidade quanto à estruturação de textos, considerando a pertinência da representação de mundo por meio de códigos semióticos do sistema comunicativo que culminaram na representação multimodal, potencializada cada vez mais pelas tecnologias digitais.

As tecnologias digitais têm permitido o surgimento de gêneros e a remodelagem de outros, com integração de imagens, animações, vídeos e inúmeros recursos para processar o sentido dos textos, disponibilizando um amplo conjunto de modos, muitas vezes em novas relações intersemióticas (JEWITT, 2013). Diante da relevância de compreender a natureza constitutiva dos mais diversos textos e suas imbricações com o contexto social e cultural, influenciado pelas ferramentas tecnológicas digitais, este estudo objetiva discutir a multimodalidade presente no gênero meme. Pautados em uma análise multimodal, à luz dos pressupostos teóricos elencados por Jewitt (2013) e Hiippala (2014), apresentaremos alguns memes recolhidos no Facebook, estabelecendo uma taxonomia desses autores para a observação da multimodalidade relacionada aos principais usos desse gênero como dinâmica social.

\section{AS MUDANÇAS NA LINGUAGEM EMERGENTES DAS TECNOLOGIAS DIGITAIS NO CONTEXTO DA MULTIMODALIDADE}

O cenário contemporâneo de modo de vida na sociedade representou grandes rupturas e significativas tendências associadas às manifestações sociais e linguísticas advindas das tecnologias digitais, como o uso de redes sociais aproximando pessoas e a interação por meio de smartphones e computadores. A comunicação não poderia ficar imune às transformações provocadas pela consolidação da internet, considerando a diversidade de registros e as variedades linguísticas presentes nesse ambiente (BEZERRA, 2013). Conforme Rajagopalan (2013, p. 50), na web "a escrita, a fala e a imagem se mesclam de certa forma, até pouco tempo atrás, impensável". 


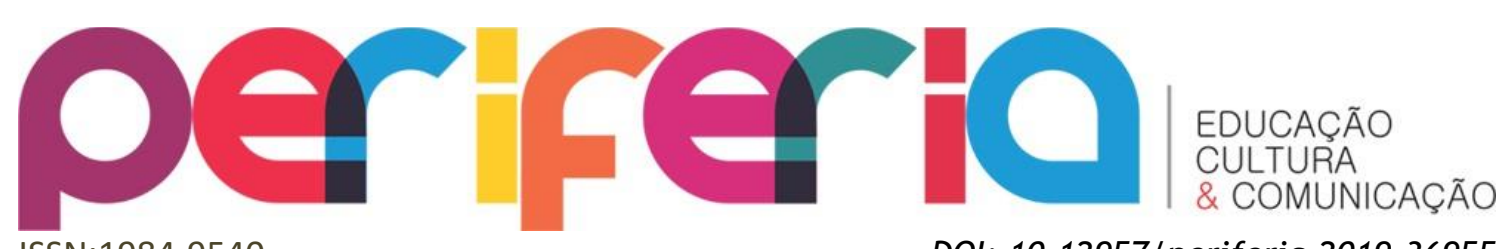

ISSN:1984-9540

DOI: 10.12957/periferia.2019.36955

Esse ambiente tão eclético, aberto a uma imensidade de formas enunciativas, possibilita uma variedade de comunicação em inúmeros aspectos multimodais que se fundem para criar os mais originais efeitos nos discursos com aliados como diferentes fontes, vídeos, imagens e layouts a serviço das interações sociocomunicativas.

A coleta e análise desses recursos semióticos encontra conceitos e métodos na multimodalidade, abordagem interdisciplinar advinda da semiótica social que compreende a comunicação para além da linguagem, atendendo sistematicamente à interpretação de uma série de representações de sentido (JEWITT, 2013). Assim, a multimodalidade reforça a ação situada, atribuindo valor ao contexto social e aos recursos utilizados para a construção de significado, partindo de um conjunto multimodal que permitirá alcançar os propósitos para os quais o enunciador fez suas escolhas. Cope e Kalantzis (2009) associam à multimodalidade a ideia de que todos os modos trabalham em conjunto. Para os autores,

o significado multimodal também é muito mais do que a soma de aspectos linguísticos, visuais, espaciais, modos de significado gestual e auditivo. Envolve também processos de integração e movimentação com ênfase para trás e para frente entre os vários modos ${ }^{2}$ (COPE; KALAMTZIS, 2009, p. 422-423).

Esses modos, realizados socialmente como um recurso situado, têm o potencial de contribuir para o significado da comunicação tanto quanto a fala e a escrita (JEWITT, 2013). Assim, a linguagem, em seus usos culturais, históricos e sociais, estabelece um sentido orquestrado pela configuração de sua estrutura interativa entre todas as escolhas para a comunicação. Jewitt (2013) observa conceitos fundamentais para atribuir significados aos textos multimodais:

(a) modos - referem-se aos recursos utilizados para dar significado aos conteúdos, que são selecionados para representar o mundo e a experiência das pessoas. Precisam incluir um conjunto de elementos e princípios de

\footnotetext{
${ }^{2}$ No original: "multimodal meaning is also much more than the sum of linguistic, visual, spatial, gestural and audio modes of meaning. It also involves processes of integration and moving the emphasis backwards and forwards between the various modes".
} 


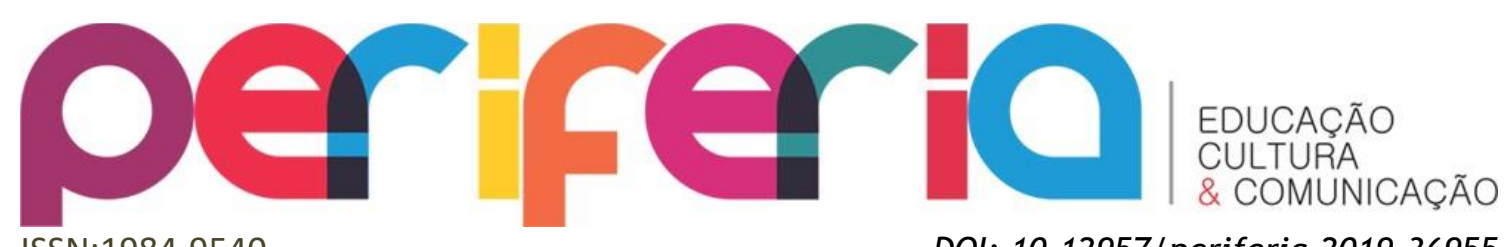

ISSN:1984-9540

DOI: $10.12957 /$ periferia.2019.36955

organização/normas dentro de uma comunidade. Para a percepção desse conjunto, Halliday (1975) observa a necessidade de articular três significados: o ideacional (experiência do falante do mundo real ou de seu universo subjetivo); o interpessoal (relações nas quais o falante expressa seu papel social); e o textual (capacidade do indivíduo - falante ou escritor - para criar texto ou distinguir um texto de um grupo aleatório de frases). Entre os modos podemos incluir escrita, imagem, fala, gesto, postura corporal e olhar.

(b) recursos semióticos - são ações, materiais e artefatos usados com fins comunicativos. Podem ser tanto fisiológicos - como mover músculos acentuando as rugas entre as sobrancelhas para indicar dúvida, preocupação ou espanto - quanto tecnológicos, por exemplo, canetas e lápis, software de computador. Kress (2009) destaca que esses recursos são constantemente transformados, considerando a combinação efetivada pra refletir interesses pessoais.

(c) materialidade - refere-se ao material físico dos recursos semióticos, com diferentes possibilidades, por exemplo, trabalhar o som para se tornar discurso ou música. É por meio da materialidade que alcançamos inúmeros objetivos comunicacionais.

(d) affordances modais - diz respeito às potencialidades e restrições dos diferentes modos, ou seja, ao que pode ou não configurar uma estratégia de comunicação facilmente identificada em um recurso. É um conceito complexo, conectado tanto ao material quanto ao contexto cultural, social e histórico de um modo.

(e) conjuntos multimodais - são representações ou interações que consistem em mais de um modo, podendo ser vistos, portanto, como resultado de modos e affordances modais, tecnologia disponível e agência de um indivíduo. Quando vários modos estão envolvidos em um ato comunicativo, eles se combinam para representar o significado da imagem.

(f) funções de significado - construídas sobre uma teoria funcional do significado como ação social, realizam-se por meio de escolhas modais das pessoas e pela maneira como elas combinam e organizam esses recursos em conjuntos 


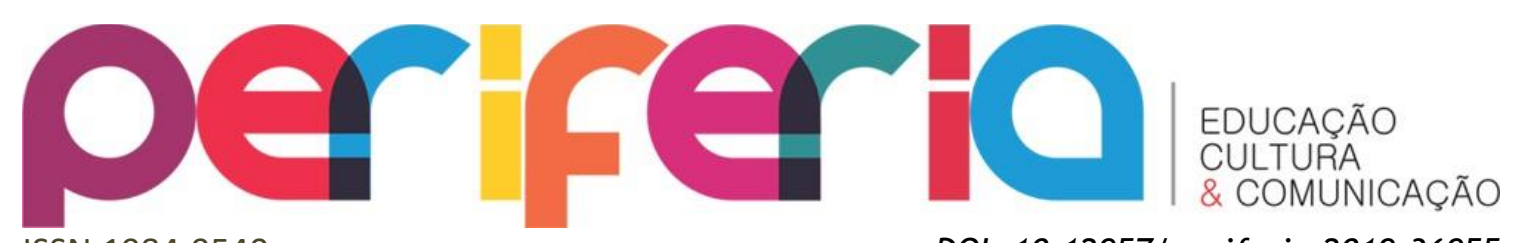

ISSN:1984-9540

multimodais. Três categorias se realizam simultaneamente: (a) significado de conteúdos, ou seja, recursos escolhidos para representar o mundo e a experiência dos sujeitos; (b) forma de significados, isto é, escolhas para representar as relações sociais entre interlocutores; e (c) significado textual ou organizacional, referente à escolha de recursos como espaço, layout e ritmo para estabelecer a coesão, composição e estrutura de um texto ou de uma interação.

A materialização dos significados nos textos multimodais, para atingir seus propósitos comunicativos, necessita de recursos semióticos que, com as tecnologias digitais, podem ser imagens, sons, vídeos e gifs, significando as potencialidades e restrições do uso de determinado objeto por uma convenção social, como no caso de emojis como forma de expressar sentimentos em substituição a palavras. Para Jewitt (2013), a construção de sentidos nos textos ocorre graças ao envolvimento de conjuntos multimodais, ou seja, o contexto social, modos disponíveis, affordances modais, tecnologias disponíveis e a agência de um indivíduo.

A atribuição desses significados nos permite observar, então, que a multimodalidade, materializada pelas tecnologias digitais, vai traçando caminhos para um sujeito cognitivo não apenas na condição de receptor, mas também de alguém que identifica potencialidades para registros de sua própria prática. Tem sido cada vez mais recorrente a forma de comunicação no espaço digital mesclando palavras e imagens, textos em movimento, com áudio e vídeo. Assim, as transmutações das práticas de linguagem vão originando gêneros discursivos que emergem no ambiente cibernético, como memes, tweets, gifs.

Nesse cenário, sob um ponto de vista histórico dos gêneros que se transformam ao longo da evolução da sociedade, há que se considerar uma ótica multimodal de análise. Concebendo que o discurso envolve uma prática de representação e de significado, os textos multimodais têm sido objeto de estudos pela pluralidade de seus códigos e elementos formadores (KRESS; VAN LEEUWEN, 1996; JOLY, 1996; ROSE, 2016). Hiippala (2014) contribui para a análise da estrutura de documentos multimodais conduzindo uma discussão teórica com o modelo Gênero Multimodal 


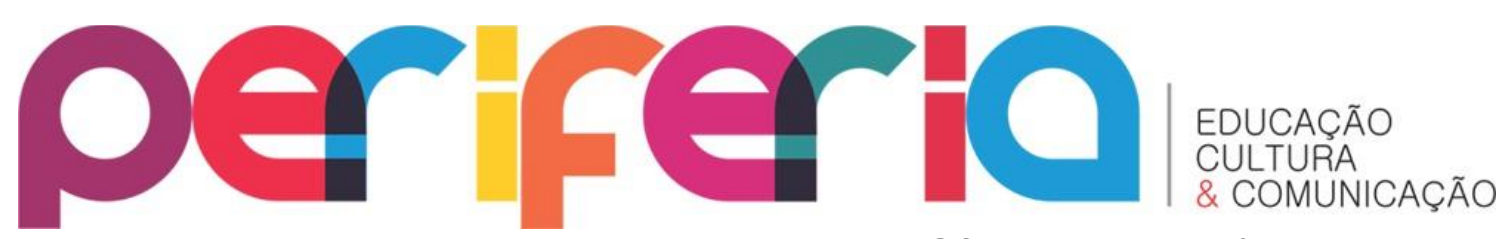

ISSN:1984-9540

DOI: $10.12957 /$ periferia.2019.36955

(doravante GeM), usado para identificar e capturar aspectos da organização do gênero em artefatos multimodais. Segundo o autor, o que caracteriza um gênero multimodal são as seguintes camadas:

(a) base: elementos básicos fisicamente presentes nas páginas, como frases, títulos, imagens, legendas etc.;

(b) layout: estrutura, modelo de área e realização em conjunto, como parágrafos, títulos, figuras, itens de lista etc.;

(c) retórica: detalhes das relações retóricas entre o conteúdo apresentado pelos elementos da página e seu propósito sociocomunicativo; e

(d) navegação: elementos que contribuem para navegação e acesso à página, como ponteiros, entradas e índices.

Segundo Bateman (2008, p. 2), "a ascendência do documento multimodal é também acompanhada e acelerada pelo enorme crescimento das tecnologias por meio das quais tais documentos são produzidos, distribuídos e consumido". ${ }^{3} \mathrm{O}$ autor observa como consequência um notável aumento da complexidade de análise sobre esses documentos, assim como lacunas substanciais para sua compreensão. A fim de aprofundar o entendimento sobre como se explicita a multimodalidade em ambiente virtual, buscamos na rede social Facebook nossos objetos de pesquisa e retomamos os pontos destacados por Jewitt (2013) e Hiippala (2014) como suporte desta análise. Inicialmente apresentaremos o histórico dos memes para, em seguida, investigarmos a compreensão dos significados expressos pelas análises multimodais dos dois autores, considerando os pontos em comum entre eles que possam levar a uma comunicação expressa pelos memes.

\section{MEMES: ARTEFATOS CULTURAIS DIGITAIS}

\footnotetext{
${ }^{3}$ No original: "The ascendancy of the multimodal document is also accompanied and accelerated by the dramatic growth of the technologies by which such documents are produced, distributed and consumed".
} 


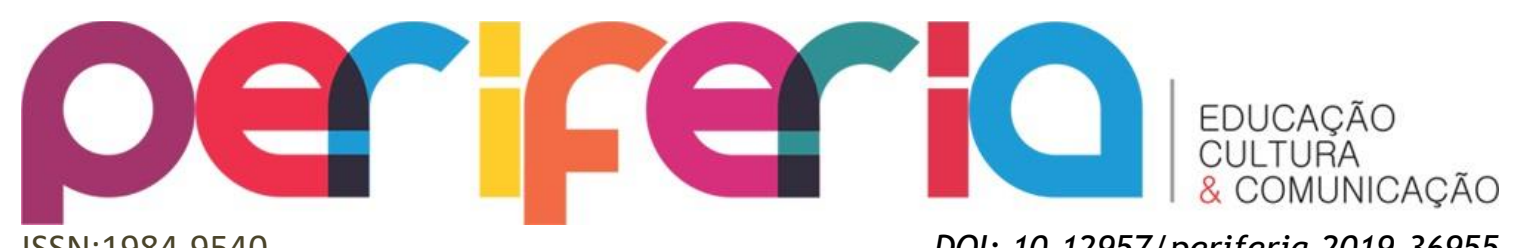

ISSN:1984-9540

DOI: $10.12957 /$ periferia.2019.36955

Um gênero textual não representa apenas a materialização do texto, mas, sim, um instrumento pelo qual podemos expressar nosso discurso, em uma posição de sujeitos críticos, reflexivos e participativos do ambiente social, cultural e histórico em que nos inserimos (BAKHTIN, 1992). É por meio da linguagem que nos expressamos. Segundo o dicionário Houaiss da Língua Portuguesa (2009, p. 1183), linguagem é "qualquer meio sistemático de comunicar ideias ou sentimentos através de signos convencionais, sonoros, gráficos, gestuais". Desse modo, os seres humanos constroem mensagens ou discursos considerando seu propósito comunicativo, a situação envolvida, os receptores do texto, o ambiente, entre outros fatores, utilizando-se, para tanto, de diferentes gêneros. Com o advento das tecnologias digitais, as estratégias de comunicação encontraram um ambiente fértil para os gêneros textuais que se apropriam de variados recursos semióticos para veicular ideias, valores, sentimentos e pontos de vista de maneira diferenciada.

Dentre os gêneros emergentes do meio digital, encontram-se os memes. Esse termo tem origem no campo da biologia, mais especificadamente na genética, quando o biólogo e escritor Richard Dawkins, em 1976, relacionou a palavra à capacidade de multiplicação dos genes (CANDIDO; GOMES, 2015). Nessa perspectiva, assim como os genes são capazes de se replicar e de transmitir informações sobre os aspectos genéticos do ser humano, os memes reproduzem e disseminam aspectos comunicacionais. As affordances do mundo digital disponibilizaram ao usuário as ferramentas necessárias para produzir, propagar, recategorizar, replicar e armazenar, com diferentes estruturas e conteúdos, esse gênero. Os memes são construídos por uma imagem já existente, retirada de fatos do cotidiano, e um texto que também parte de outro contexto para se configurar em uma significação final.

Knobel e Lankshear (2007, p. 202) conceituam meme como "um termo popular para descrever a rápida aceitação e propagação de uma ideia particular apresentada como um texto, imagem, linguagem, 'movimento', ou alguma outra unidade de 'material' cultural”. ${ }^{4}$ Os memes chamam atenção por sua dinamicidade e

\footnotetext{
${ }^{4}$ No original: "a popular term for describing the rapid uptake and spread of a particular idea presented as a written text, image, language 'move', or some other unit of cultural 'stuff'."
} 


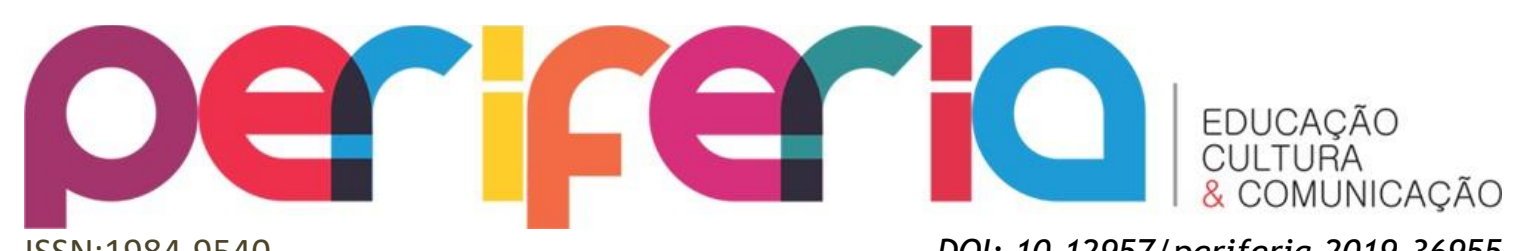

ISSN:1984-9540

multimodalidade, por constituírem um discurso onipresente em ambientes digitais como Facebook, Instagram, WhatsApp e Twitter. Na tentativa de explicar emoções intensas, declarações sobre inúmeros assuntos, sentimentos e posições políticas, sociais, econômicas e afetivas, os memes surgem como representações de uma cultura contemporânea com implicações fluidas, e se propagam rapidamente.

De acordo com Shifman (2013), os memes podem ser interpretados como unidades da cultura popular veiculadas, imitadas e transformadas por usuários da internet, criando uma experiência cultural compartilhada. 0 autor discute três dimensões culturais que permitem às pessoas interagirem por meio de memes: conteúdo, forma e postura. A primeira diz respeito ao conteúdo específico, relacionado tanto às ideias quanto às ideologias transmitidas pelo meme; a segunda dimensão aborda a forma, ou seja, a materialização física da mensagem, que possibilita a percepção sensorial (visual, auditiva ou outro padrão mais complexo); e a terceira considera a postura, a posição que os usuários assumem diante do gênero meme, por exemplo, a decisão de compartilhar um texto ou se posicionar contrário a ele.

Assim, a cultura digital, como espaço de produção e transmissão de saberes, permite aos memes moldar mentalidades e comportamentos de grupos sociais (KNOBEL; LANKSHEAR, 2007). Shifman (2013) observa que nesse fenômeno social, embora o meme se espalhe em uma base micro, seu impacto está no macro; ou seja, pela velocidade e alcance de disseminação, ele se torna uma rica ferramenta de divulgação cultural.

Em sua simplicidade, os memes podem ser produzidos com qualquer programa editor de texto para computador. Correndo o risco de nos tornarmos obsoletos nesta informação, diante da rapidez das evoluções tecnológicas digitais, destacamos alguns recursos que permitem a construção de memes, como Meme Generator, Livememe, Quickmeme, MemeDad, Imgflip, ou até mesmo o Paint, além de ferramentas para celular, como Pext, Aviary Photo Editor, Picsart, Photogrid ou Cymera. Martino (2015, p. 178) destaca que "qualquer pessoa com conhecimentos rudimentares de edição de imagem digital pode, potencialmente, se apropriar de uma ideia, modificá-la e compartilhá-la”, característica intrínseca aos memes. 


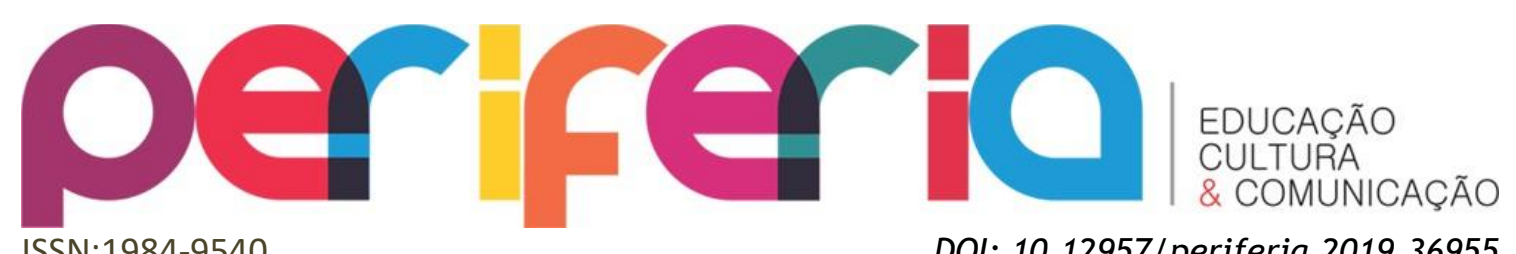

ISSN:1984-9540

DOI: 10.12957/periferia.2019.36955

Assim, elaborados com a junção entre uma imagem retirada de determinada cena do cotidiano e um texto extraído de outro contexto, o meme vai adquirindo uma significação própria.

A seguir, exploramos a aplicabilidade de memes na cultura digital, mais especificamente no Facebook, posicionando-nos quanto suas estruturas constitutivas e estratégias discursivas.

\section{ANÁLISES E DISCUSSÕES}

O uso recorrente de imagens nas comunicações tem propiciado um movimento da linguagem por um processo criativo de memes em redes sociais, carregando emoções, ideias, pontos de vista, comportamentos, valores e inúmeros argumentos de forma diferenciada em processos discursivos. A proposta deste trabalho é observar os aspectos de compreensão e produção de sentidos que envolvem o gênero meme. Nesse cenário, pautados nos aportes teóricos de Jewitt (2013) e Hiippala (2014), selecionamos onze memes coletados aleatoriamente no Facebook, sobre diversos assuntos.

Iniciamos com a apresentação de uma página o Facebook e, em seguida, elencamos alguns memes que fazem parte da linha do tempo da autora. 0 objetivo é examinar os aspectos multimodais presentes nos memes, assim como as possibilidades de recepção de significados interpostos no gênero multimodal. Essa investigação se enquadra nos parâmetros qualitativos, uma vez que intencionamos abordar os recursos semióticos para a determinação das informações veiculadas.

Hiippala (2014) viabilizou um framework que permite analisar como os documentos multimodais são distribuídos conforme o modelo GeM. Iniciamos nossas observações demonstrando o papel de ligação da camada base, ou seja, é a camada responsável pela consubstanciação de todo o documento multimodal. A Figura 1 retrata uma página do Facebook, permitindo analisá-la quanto às unidades mínimas que compõem a camada base:

Figura 1: Camada base do Facebook 

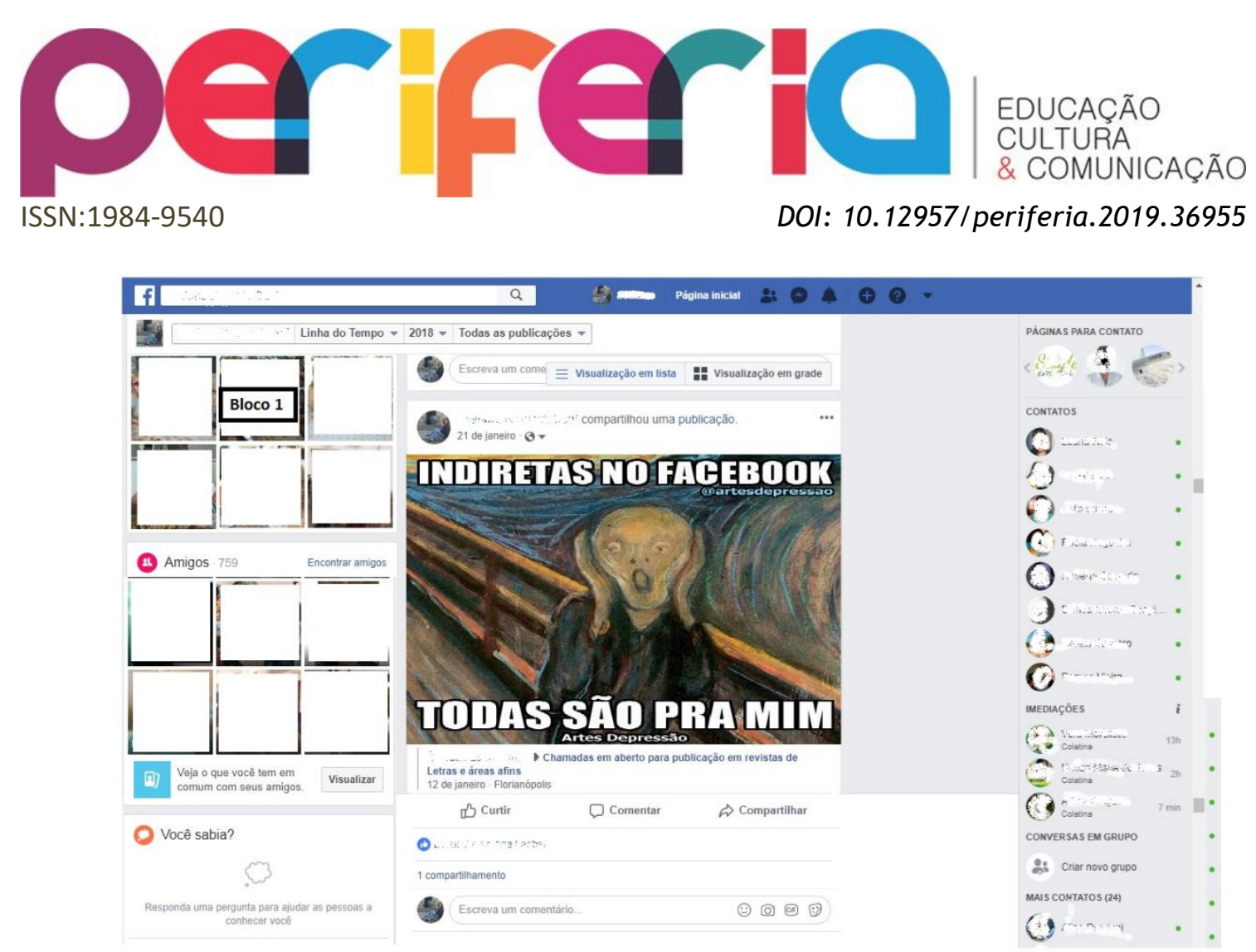

Fonte: Página articular da autora no Facebook.

A partir da Figura 1 podemos considerar que o conjunto de uma página no Facebook é mutável, ou seja, embora os aspectos de layout que atribuem identidade à página se mantenham fixos, o espaço permite que seus usuários personalizem a página com fotos, cores e textos escritos diariamente. São esses recursos que propiciam a decomposição da camada base em suas unidades mínimas, segundo o modelo GeM (HIIPPALA, 2013). Com uma estrutura plana, a página oferece quatro grandes blocos: na lateral esquerda, o espaço para Fotos e Amigos; à direita, amigos online, nas imediações e conversas de grupo; e centralizado, o post atual - no caso, um meme. Então, a camada de base é formada por links, imagens e textos, permitindo ao usuário construir sentido e identidade para sua página pessoal.

Segundo Bateman (2008), há um vocabulário básico de identificação para dar significado a uma página ou documento, sendo papel do investigador conferir sentido às interpretações ali apresentadas, a fim de possibilitar a interação dos elementos para a análise das outras camadas. Assim, a página abarca questões tanto de cunho genérico quanto retórico e de navegação, procedendo suas correlações de acordo com seus usuários, sem estrutura direcional. Observamos também na página camadas de navegação (HIIPPALA, 2014), por meio de links interativos de Curtir, Comentar e Compartilhar relacionados ao meme, além da possibilidade de postar textos, vídeos 


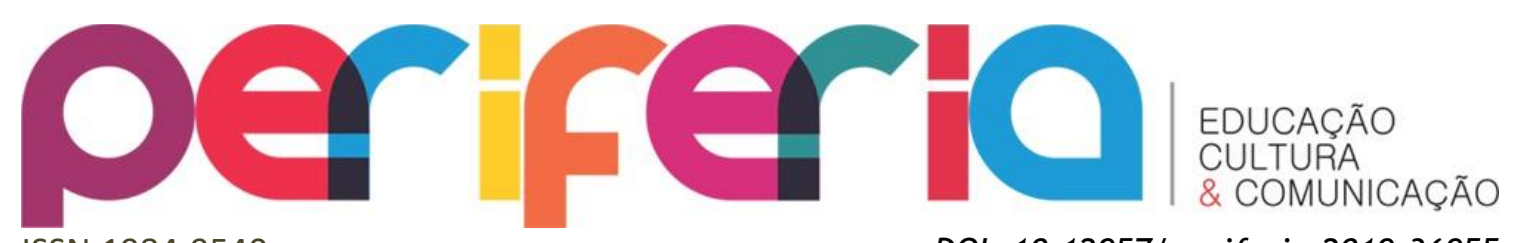

e fotos, interagir com as pessoas, individualmente ou em grupo, encontrar coisas ou pessoas no sistema de busca etc.

Quanto ao meme utilizado na página, destacamos sua camada retórica (HIIPPALA, 2014) pelos detalhamentos de suas relações com a imagem escolhida. 0 quadro $O$ Grito, que serviu como referência para o meme, é do pintor norueguês Edvard Munch e retrata uma figura andrógena em um momento de profunda angústia e desespero existencial. Situação semelhante ocorre com a personagem do meme, isto é, ela se encontra em um momento de pânico ao deparar a ideia de que qualquer post na internet esteja relacionado a ela. Referimo-nos, então, baseados em Hiippala (2014), à intenção interacional no uso do computador para transmitir um significado interpessoal: a personagem expressa, por meio da rede social, seus sentimentos de medo e insegurança.

Podemos perceber também o que Jewitt (2013) assinala como affordance modal, ou seja, ao mesmo tempo que a imagem potencializa a leitura do meme, ela passa a restringir o sentido se o leitor não conectar seu uso histórico, social e cultural ao quadro de Munch. 


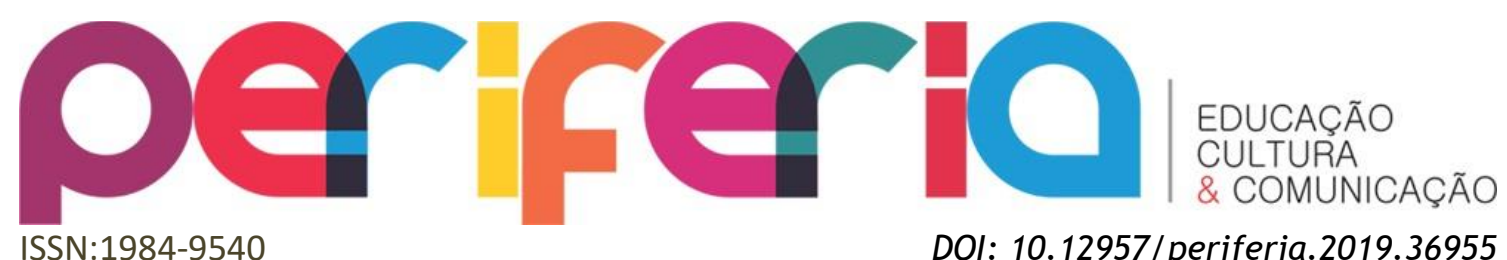

Figura 2: Quadro $O$ Grito, do pintor Edvard Munch

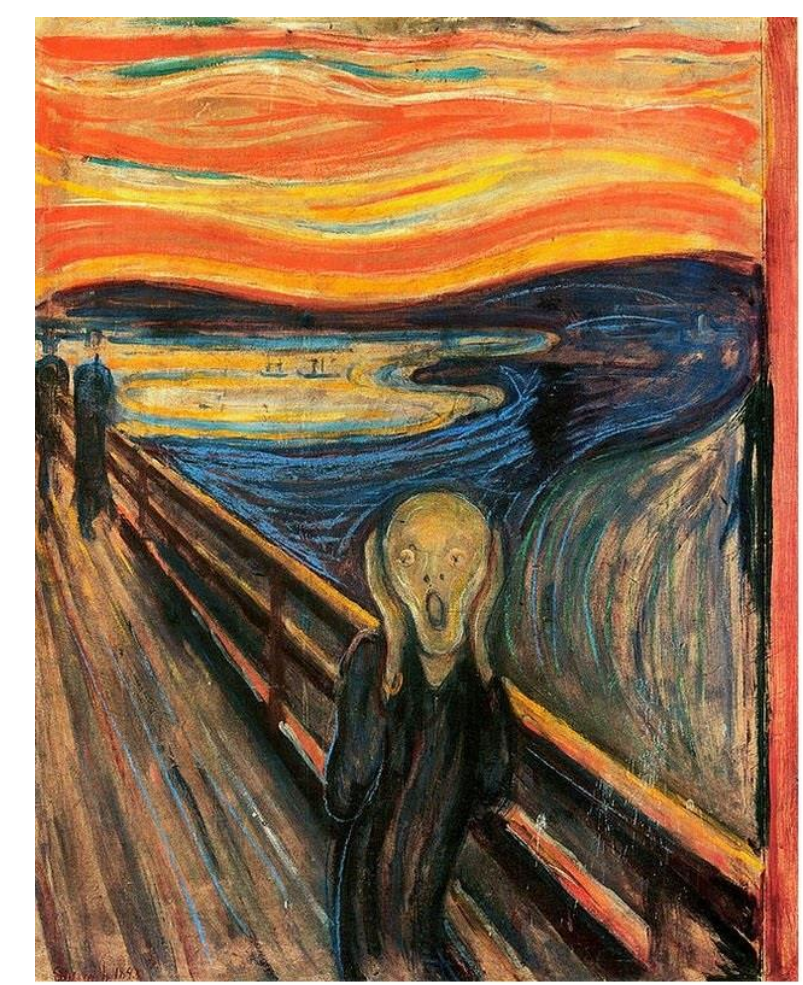

Fonte: https://www.pinterest.co.kr/pin/398990848213227143/?lp=true

Embora a expressão física no meme, inclusive com gotas de suor, demonstre sentimentos similares aos do quadro original, o entendimento sobre a obra levaria a um espaço particular de conhecimento de mundo. Assim, recorremos a Jewitt (2013) para tratar a atribuição dos significados multimodais do texto, gestados pelo uso do quadro $O$ Grito para representar o mundo e as experiências da personagem, transmitindo um significado pessoal de insegurança em relação à sua participação no Facebook. Desse modo, a referência textual, apontada por Jewitt (2013) como atribuição do significado, torna o meme uma "paródia" do quadro original, na qual paisagem, layout, jogo de cores, ondulações e elementos físicos da personagem contribuem para uma releitura cômica da composição artística. Destacamos também a conexão interacional para transmissão da mensagem entre o uso do computador, a divulgação do Facebook e a utilização metalinguística do meme para falar da própria rede social.

Knobel e Lankshear (2007) identificam essas referências cruzadas com uma série de eventos, artefatos e práticas da cultura popular como meme intertextual, 


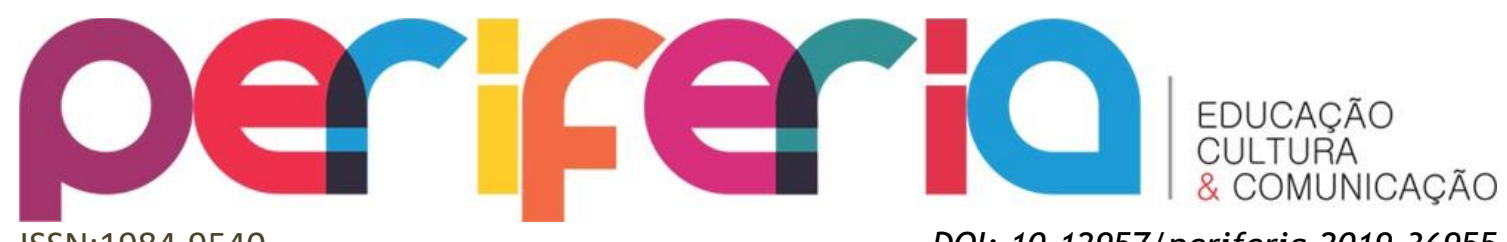

ISSN:1984-9540

DOI: 10.12957/periferia.2019.36955

que permite às formas de comunicação se encaixarem em um espaço de afinidade para dar sentido a uma ideia. No entanto, a formação cultural do leitor é essencial para a leitura crítica das metáforas existentes na imagem. Chen (2012) observa a importância da internet como espaço público de democratização do conhecimento. Segundo o autor, os memes são responsáveis por propagar conteúdos importantes, que argumentam a favor de ideias diversas, influenciando sobremaneira os interesses sociais, como na Figura 3:

Figura 3: Meme acerca do meio ambiente

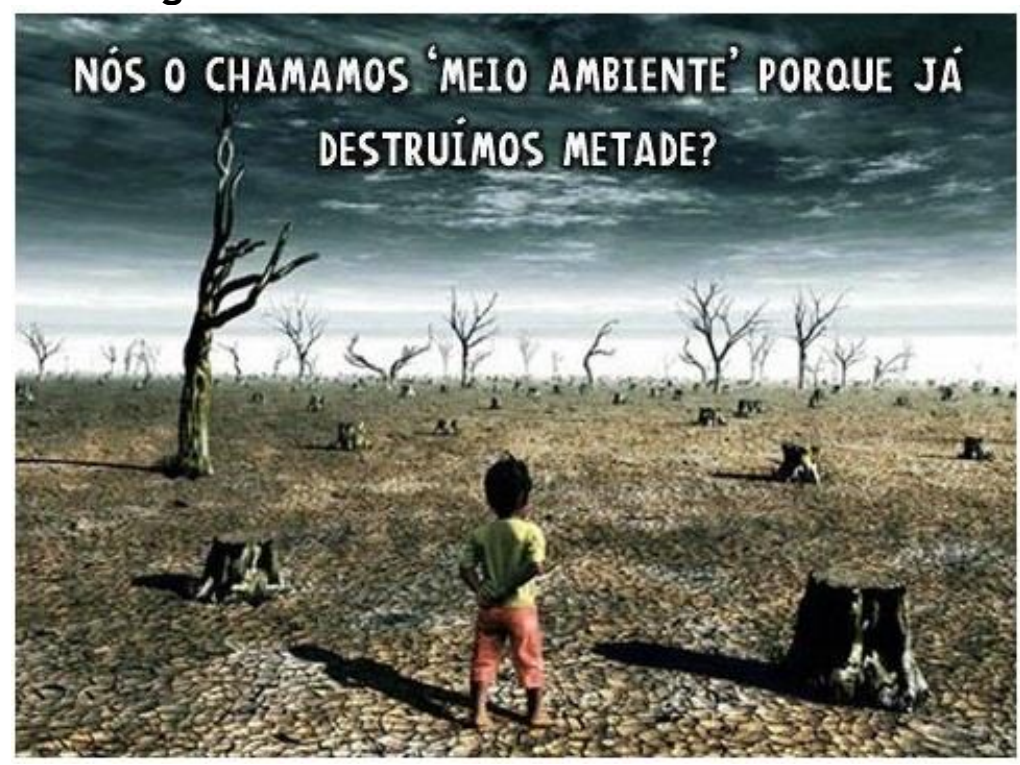

Fonte: http://kdimagens.com/imagem/nos-o-chamamos-meio-ambiente-porque-ja-destruimosmetade- $1572^{5}$

Conforme Jewitt (2013), os modos se relacionam aos recursos utilizados para dar significado ao texto. No meme da Figura 3 destacamos dois conceitos fundamentais apontados pelo autor, a respeito do significado de representações imagéticas: (a) materialidade - o aspecto da criança (suas condições da roupa) e as cores utilizadas, representativas do sol (amarelo) e do fogo das queimadas (vermelho), somados à paisagem, reforçam a ideia de desolação da humanidade, tanto pela representação de uma criança (significando dúvida quanto ao futuro)

\footnotetext{
${ }^{5}$ Símbolo utilizado como substituição à página particular da autora.
} 


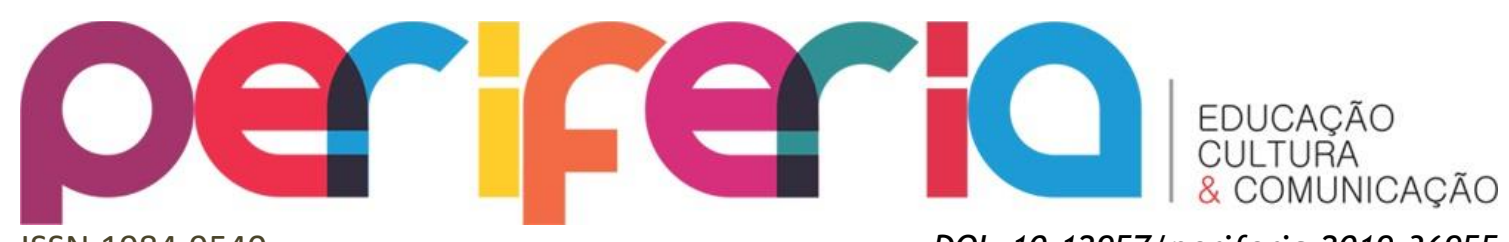

ISSN:1984-9540

DOI: $10.12957 /$ periferia.2019.36955

como pela devastação das árvores, as cores sombrias do chão seco e queimado e o céu cinza, intensificando o plano de profundidade como se os caminhos dos olhos não permitissem uma saída para a problemática; e (b) conjunto multimodal - a floresta devastada e a imagem de uma criança reforçam uma intertextualidade que não se encontra apenas no âmbito linguístico (compreensão de meio ambiente como conjunto que envolve todas as coisas presentes no planeta Terra ou como metade do ambiente), mas em todos os aspectos relacionados à experiência das pessoas para representar a comunicação, ou seja, a composição dos recursos utilizados dão sentido ao texto.

Essas estratégias permitem identificar as affordances modais presentes do texto, pois passam a estabelecer uma forma de comunicação facilmente identificada no meio cultural, social e principalmente histórico relacionado aos problemas ambientais. Quanto ao layout - criança, terra seca e devastada por queimadas e um céu cinzento e escuro - Hiippala (2014) afirma ser uma camada retórica, estratégia para ampliar a eficácia da mensagem oferecida à nossa interpretação de que é preciso cuidar do meio ambiente.

O humor é um componente peculiar em grande parte dos memes. Os próximos exemplos abordados discutem essa particularidade do gênero em pauta.

Figura 4: Memes sobre o Exame Nacional do Ensino Médio

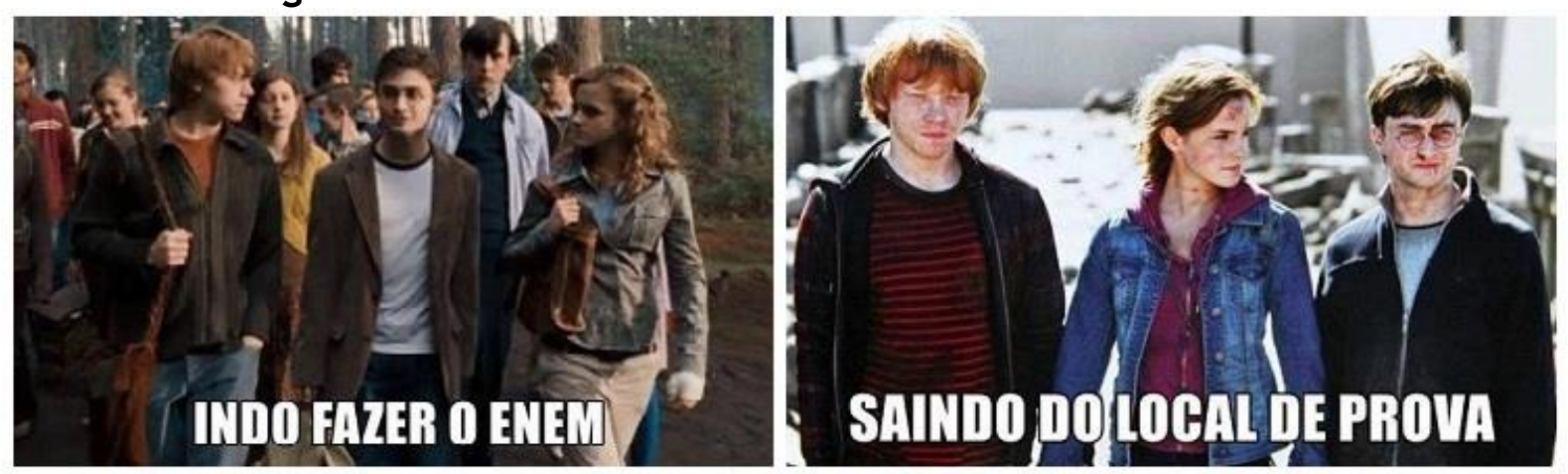

Fonte:

http://www.f24.com.br/editorial/educacao/2014/11/09/228151-aprendinoeneminternautas-repercutem-o-enem-nas-redes-sociais

A sátira contida nas figuras corresponde a manifestações populares a respeito da prova cujo objetivo é verificar competências e habilidades dos estudantes que concluíram o ensino médio e, com base nisso, permitir a entrada em universidades. 


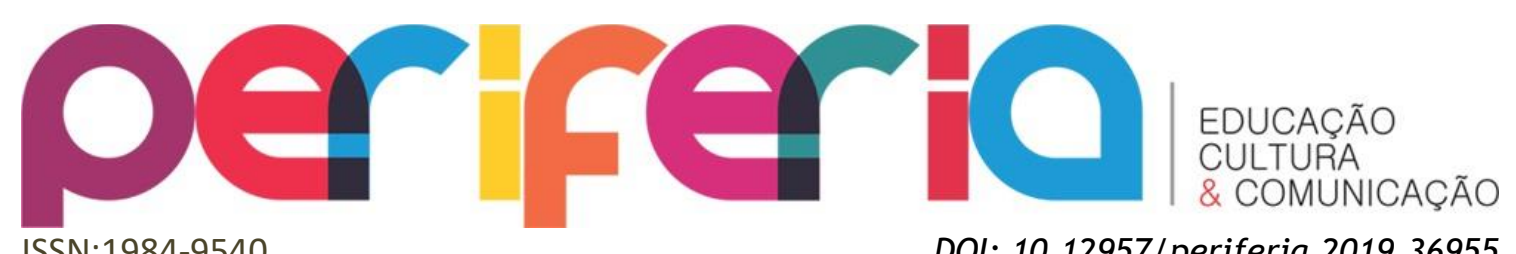

ISSN:1984-9540

DOI: 10.12957/periferia.2019.36955

Bizarramente engraçado, o meme, conforme já apontamos, é constituído por uma imagem preexistente (na Figura 4, jovens personagens de um filme) e um texto de outro contexto (no caso, a referência ao Enem) para se configurar em uma significação final.

Assim, o propósito comunicacional do meme na Figura 4 identifica a forma física (diríamos também emocional) dos participantes do processo avaliativo, que chegam à exaustão após as provas. A esse respeito, Jewitt (2013) observa que a materialização dos significados em textos multimodais, para atingir suas intenções comunicativas, requer entendimento por parte do leitor. Esse meme, para nós brasileiros, seria compreendido com facilidade, porém um estrangeiro provavelmente teria dificuldade para interpretar a crítica, pela falta de conhecimento prévio sobre a prova, pelas condições sociais e culturais em que muitos candidatos se encontram.

As affordances modais (JEWITT, 2013), ou seja, as potencialidades projetadas na imagem, permitem algumas análises. Primeiro, a entrada para a prova apresenta muitos jovens com aparência normal, expressando tranquilidade e coragem para enfrentar os desafios implicados no concurso. A segunda imagem, em oposição, além de expor os adolescentes saindo do evento cansados e sujos, como se tivessem acabado de sair de uma batalha, sugere que somente esses três conseguiram bom desempenho diante dos demais concorrentes, que sumiram da imagem; é possível inferir também que apenas seres com poderes especiais conseguiram realizar a prova - uma crítica sobre a dificuldade do exame representada pela atmosfera de caos. No entanto, a leitura desse texto multimodal vai além dos aspectos do Enem, abarcando um contexto situacional e sobretudo cultural, porque os jovens são personagens principais de uma série de filmes britânico-americana, baseada nos livros homônimos de J. K. Rowling, Harry Potter, Rony Weasley e Hermione Granger, que lutam contra seres das trevas que tentam controlar o mundo.

As categorias de análise do modelo GeM (HIIPPALA, 2014) podem ser assim representadas: a camada base são imagens e textos; o layout se configura por (a) duas imagem - a primeira com três jovens protagonistas no centro, limpos, de expressão facial tranquila e acompanhados por outros jovens; a segunda, com três 


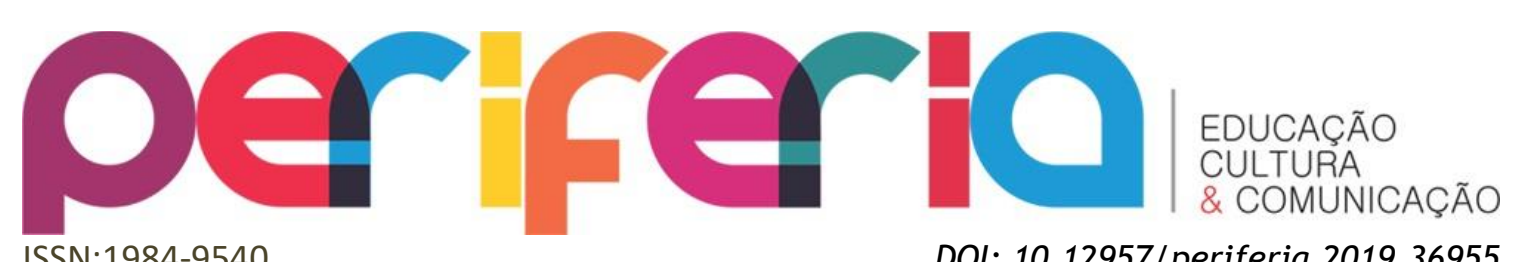

ISSN:1984-9540

DOI: $10.12957 /$ periferia.2019.36955

protagonistas sozinhos, marcados por luta (sangue na boca, testa e nariz), sobrepostos a uma imagem desfocada, sem outros jovens em segundo plano, transmitindo a ideia de um ambiente destruído - e (b) dois textos, com a particularidade de um se encontrar na primeira imagem e outro na segunda, no entanto, os textos se completam, surgindo uma camada de navegação na qual a leitura do meme da esquerda será completada pelo da direita.

Os memes a seguir, também de humor, trazem personagens da Disney, especificamente princesas, como protagonistas de situações do dia a dia, satirizando problemas femininos.

Figura 5: Memes com princesas

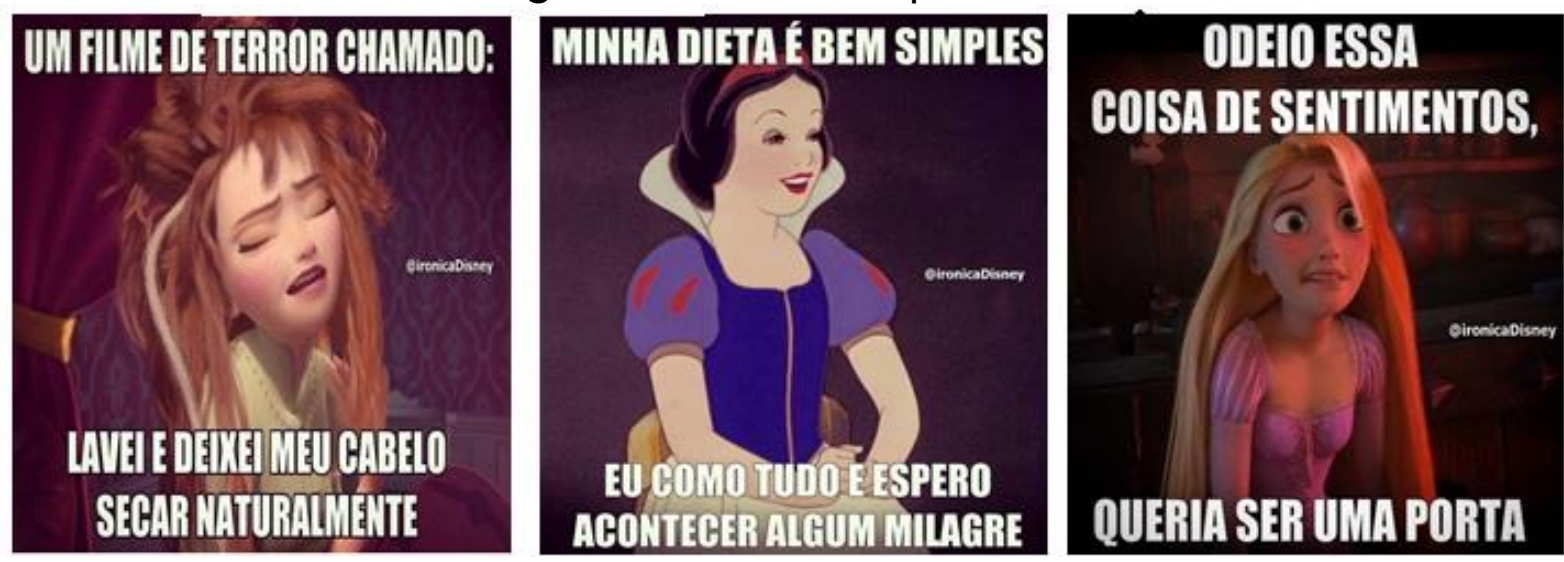

Fonte: https://www.facebook.com/disneyironica

O contexto de abordagem semiótica dos memes se materializa de forma colaborativa por intermédio de uma imagem, com ações do cotidiano e de um texto escrito no sentido humorístico. A página de humor @ironicadisney apresenta as princesas da Disney destacando os dramas vividos em situações variadas, como problemas com o cabelo, tentativas frustradas de dietas ou expectativas criadas no dia a dia. Segundo Hiippala (2014), as escolhas do modo semiótico nos permitem perceber e comparar estruturas multimodais semelhantes. Nesse sentido, os artefatos sociais utilizados nos memes da Figura 5 realizam uma estratégia retórica comunicativa similar em sua camada base: imagem de uma princesa centralizada com textos nas partes superior e inferior. 


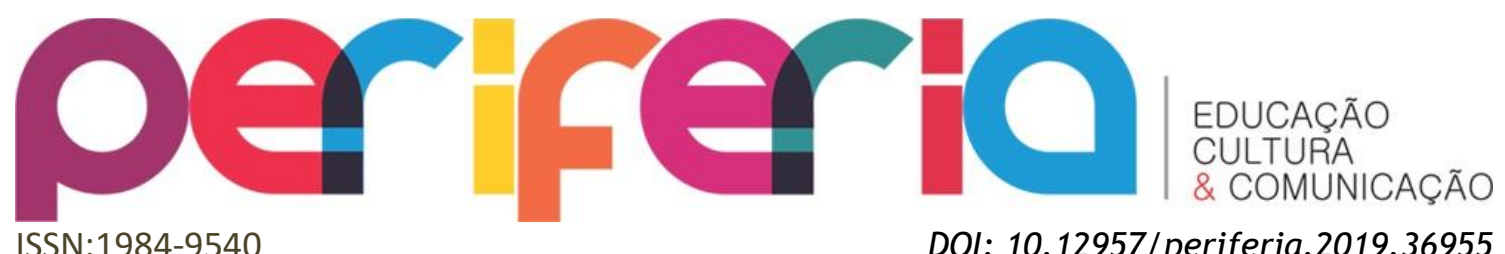

Nesse contexto, usando imagem e escrita, percebemos um layout construído a partir da forma do meme, o que Hiippala (2014) caracteriza como estrutura, modelo de área e realização. A descrição visual-verbal é resultado de escolhas que se aproximam da intenção discursiva (no primeiro meme, a situação do cabelo; no segundo, a tranquilidade da princesa para aguardar o milagre; e no terceiro, a expressão facial, sobrancelhas arqueadas e a boca com um sorriso sem graça, demonstrando uma decepção). Essa interação encontrada no layout e as funções organizadas entre suas partes permitem ao leitor entender a intenção comunicativa, ou seja, a camada retórica (HIIPPALA, 2014).

Os memes da Figura 6 estão associados a imagens de estrelas de Hollywood. A página Diva Depressão investe em um humor irreverente e original para gerar memes de frases espirituosas e divertidas sobre relacionamento, amizade e outros inúmeros assuntos do cotidiano.

Figura 6: Memes sobre mulheres "Divas"
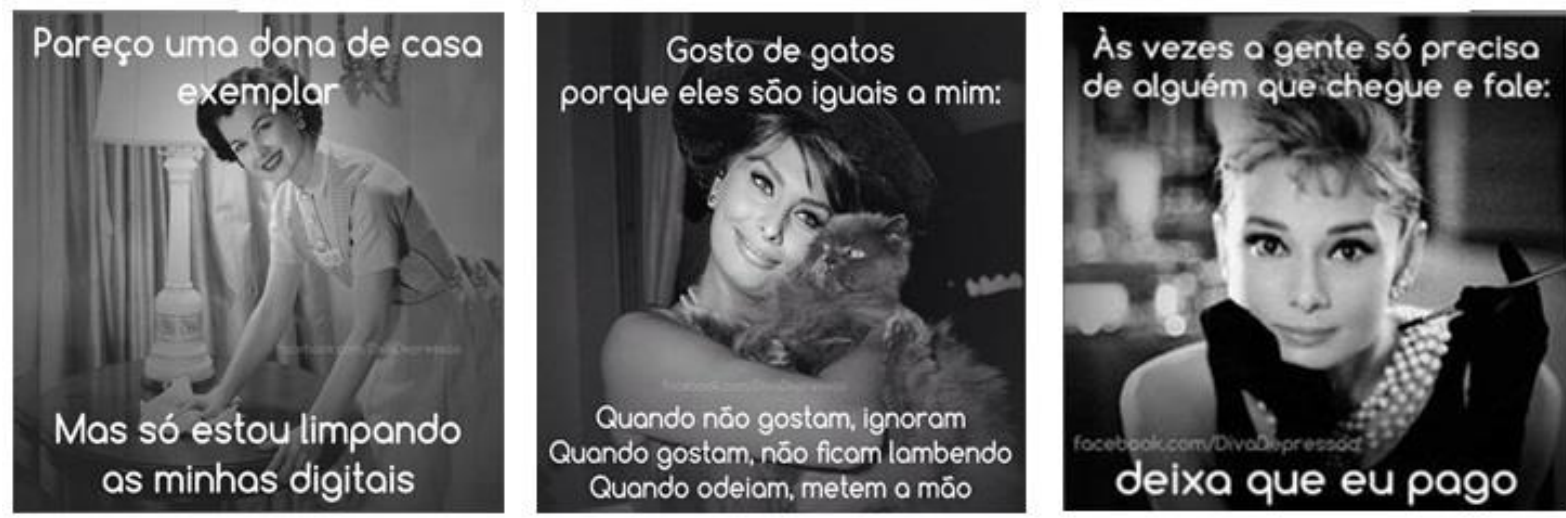

Fonte: https://www.facebook.com/DivaDepressao/

As postagens da página Diva Depressão podem ser classificadas pelos padrões discursivos como humorísticas, principalmente pela criação controversa na qual se coloca uma “diva”, ou seja, uma divindade feminina - nesse caso, uma deusa das produções hollywoodianas, com textos que não se esperam de uma mulher desse contexto. Assim, as relações retóricas presentes nesses memes se materializam no paradoxo entre o que se mostra e o que se fala, ratificando a atribuição de 


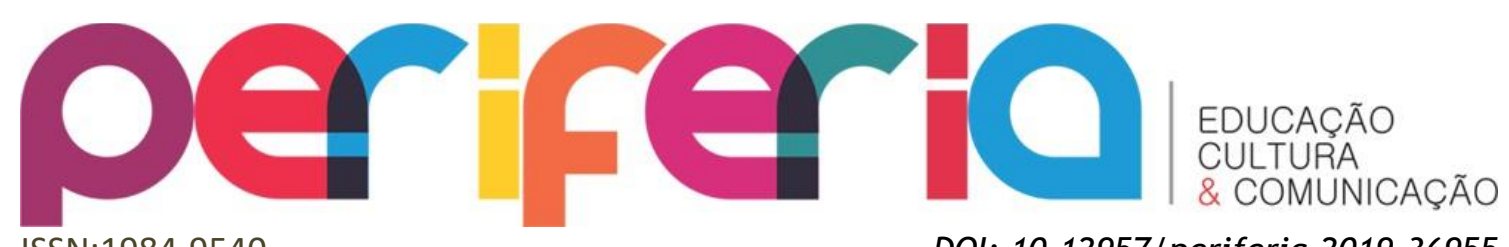

ISSN:1984-9540

DOI: 10.12957/periferia.2019.36955

significados determinada por escolhas para representar o mundo e experiências das pessoas, como aponta Jewitt (2013).

Com base no modelo GeM de Hiippala (2014), podemos caracterizar os elementos formadores dos memes aqui analisados da seguinte maneira: camada base - elementos mínimos, compostos por imagens centralizadas e em preto e branco, com textos escritos nas partes superior e inferior; layout - formado pela imagem de uma atriz famosa de Hollywood bem arrumada em uma situação do cotidiano, relacionada a uma intenção discursiva materializada pelos textos; camada retórica conteúdo imagético representado no meme (mulheres felizes, doces e ingênuas, de olhares suaves), associado ao texto superior, entra em contraste com o texto inferior, que se destaca por um propósito comunicativo de afirmar a verdadeira mulher, forte, determinada e decidida a se impor socialmente; e a camada de navegação - considera o texto superior, destacando a suavidade da mulher, o que se confirma pelo olhar, mas se desconstrói com o texto inferior.

Figura 7: Meme sobre animais de estimação

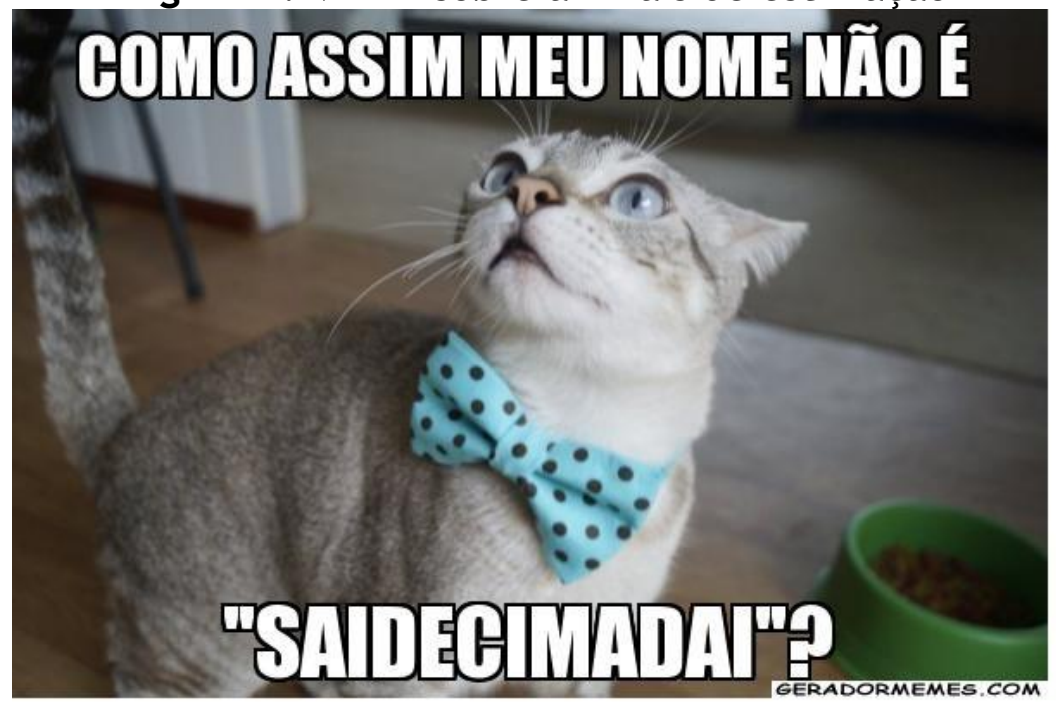

Fonte: http://geradormemes.com/meme/zja719

0 meme da Figura 7, dotado de informação visual e escrita, vai além da camada base do modelo GeM conforme assinala Hiippala (2014). Isso acontece porque a identificação das unidades mínimas de layout, responsável por dar ao meme uma estrutura estético-visual, opera de forma clara quando nos atentamos aos diferentes 


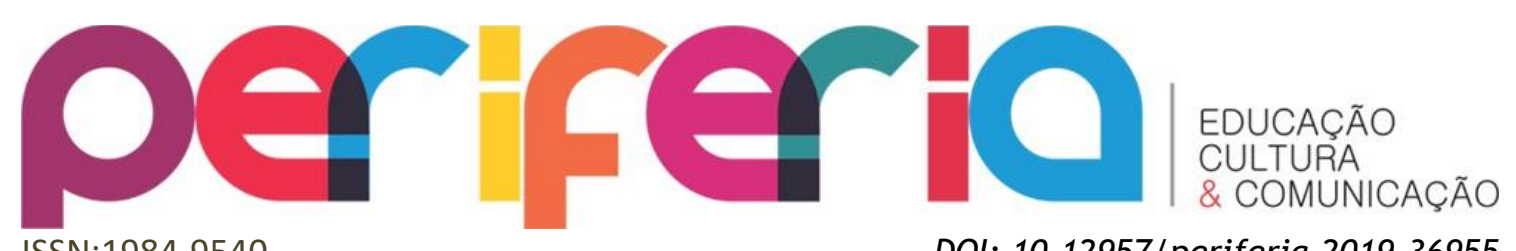

ISSN:1984-9540

DOI: $10.12957 /$ periferia.2019.36955

aspectos multimodais inerentes aos memes: imagem centralizada e textos na parte superior e inferior.

Outra observação importante diz respeito à camada de navegação, que surge pelo olhar do gatinho, um vetor de reação, ${ }^{6}$ como se fosse um ponteiro direcionando à pessoa com a qual o gato está se comunicando (KRESS; VAN LEEUWEN, 1996). Ademais, há a leitura do conteúdo escrito na parte superior da imagem, que seguiria para o escrito na parte inferior, contribuindo para articular imagem e conteúdo verbal na geração do sentido. Assim, os detalhes constitutivos do gênero meme se agrupam de forma mais abrangente, compondo o texto: o olhar desconfiado do gato (diríamos até assustado com a descoberta), para cima, expressa uma comunicação com um humano adulto, enquanto a formação textual abaixo, toda grudada, pode aludir ao jeito como provavelmente o adulto pede ao gato para descer dos lugares: com ênfase em todas as sílabas e, talvez, em um tom um pouco mais sério.

Retomando as affordances modais propostas por Jewitt (2013) em suas abordagens analíticas, destacamos na imagem a presença do laço, azul e com bolinhas, como tática cultural e social de representação do animal, ou seja, esse recurso pode indicar que se trata de um macho. Recorremos a Jewitt para analisar as funções de significado presentes no meme: os recursos escolhidos (imagem do gato, recipiente de comida e o provável ambiente de uma sala); as relações sociais entre o animal e seu dono; os cuidados que se pode observar no animal (limpo e arrumado); e a estrutura organizacional (a composição coesa entre imagem, ambiente e texto, realizados simultaneamente pelos conjuntos multimodais).

A partir das categorias de análise aqui elencadas, baseadas em Jewitt (2013) e Hiippala (2014), reconhecemos o meme como um gênero multimodal, composto por imagens, cores, textos escritos e dotado de grande potencialidade de interação e viralização em uma comunidade. O meme evoca ideias que se fundem e se combinam por meio de um fluxo de informações cuja interpretação muitas vezes exige relações dêiticas, assim como conhecimentos culturais, sociais e políticos.

\footnotetext{
${ }^{6}$ Kress e van Leeuwen chamam "vetor de reação" quando um olhar se direciona a qualquer coisa dentro de uma imagem ou fora dela.
} 


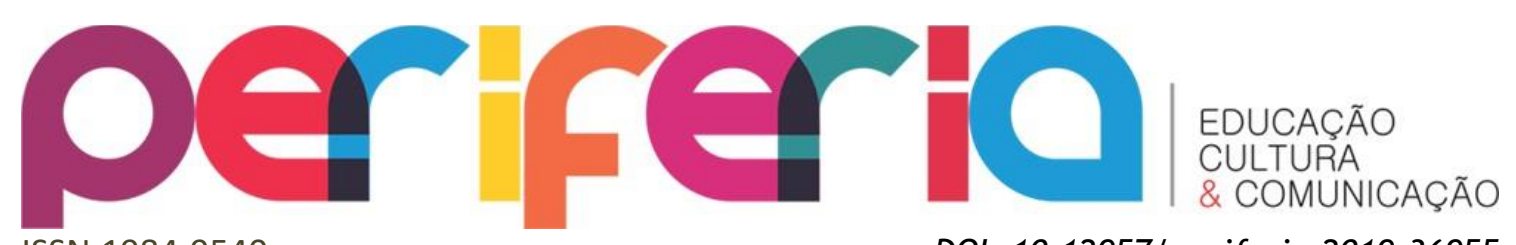

ISSN:1984-9540

DOI: $10.12957 /$ periferia.2019.36955

Nesse contexto, os memes contribuem não apenas para gerar humor, mas também para registar o pensamento humano por meio de críticas sociais. Embora não tenhamos destacado neste estudo, o movimento negativo também acontece, visto que muitos se apropriam desse gênero para a prática de bullying, por exemplo.

\section{CONSIDERAÇÕES FINAIS}

Miller (2009) observa que a internet tem sido espaço com mais liberdade que as disciplinas acadêmicas e organizações educacionais, permitindo muita experimentação e se tornando onipresente no cotidiano da sociedade. As características textuais-discursivas dos memes são reflexo das mudanças nas relações interpessoais, com propósitos diferentes, como divulgar campanhas publicitárias, fazer humor, discutir política ou outro assunto que esteja em pauta na sociedade. Assim, os memes são um gênero digital rico tanto por sua composição de fácil entendimento (foto ou outro tipo de imagem acompanhada de um enunciado escrito), quanto por sua capacidade de abordagem.

Percebemos, na perspectiva multimodal, que as camadas do modelo GeM proposto por Hiippala (2014) e aspectos da multimodalidade propostos por Jewitt (2013) contribuíram para a percepção dos elementos presentes nos memes, constituindo categorias investigativas úteis para melhor compreender esse gênero. Ambas as propostas procuram abarcar aspectos trazidos pelos gêneros multimodais, propiciando uma visão mais pormenorizada do significado expresso pelos modos semióticos presentes nos textos.

Diante disso, as escolhas realizadas pelos produtores de memes atendem a contextos culturais, sociais e políticos de naturezas distintas. Sua estrutura e organização permitem um diálogo entre produtor e leitor, por meio de um texto carregado de ideologias e conceitos que demandam dos leitores um conhecimento prévio. Esses recursos, facilmente replicados, pela mensagem, crítica, humor e principalmente pela carga emocional que contêm, podem promover grandes impactos nas práticas sociais. 


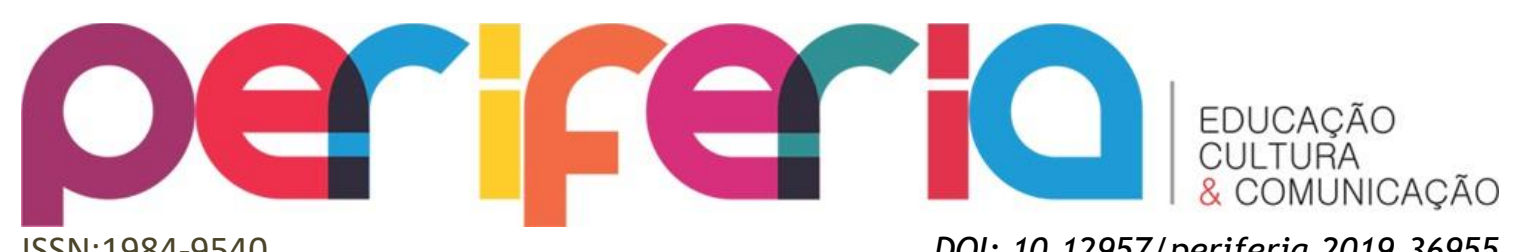

ISSN:1984-9540

DOI: 10.12957/periferia.2019.36955

Ressaltamos a importância de estudos a respeito da multimodalidade, considerando que grande parte das interpretações relacionadas aos exemplos aqui apresentados requerem análises de áreas diversas do conhecimento. Conforme adverte Bateman (2008, p. 7), “À medida que o uso de modalidades visuais interligadas cresce, devemos nos questionar se poderemos nos dar ao desfrute de continuarmos a nos apoiar em aprender sobre multimodalidade por osmose, implicitamente". ${ }^{7}$

\section{REFERÊNCIAS}

ADAM, Jean-Michel. Linguistique textuelle: des genres de discours aux texts. Paris: Nathan, 1999.

ARISTÓTELES. Arte Retórica e Arte Poética. Rio de Janeiro: Edições de Ouro, 1988. (Coleção Universidade).

BATEMAN, John. Multimodality and genre: a foundation for the systematic analysis of multimodal documents. London: Springer, 2008.

BAKHTIN, Mikhail [1977]. Os gêneros do discurso. In: verbal. São Paulo: Martins Fontes, 1992. p. 261-305. . Estética da criação

BAZERMAN, Charles. Gêneros textuais, tipificação e interação. São Paulo: Cortez, 2005.

BEZERRA, Benedito Gomes. O discurso acadêmico sobre língua e linguagem na internet. In: SIMPÓSIO HIPERTEXTO E TECNOLOGIAS NA EDUCAÇÃO, 5, 2013, Recife. Anais... Recife: Universidade Federal de Pernambuco, 2013. p. 1-20.

BREURE, L. Development of the genre concept. 2001. Disponivel em: < http://www.informationdesign.org/development_of/ >. Acesso em: 29 ago. 2018.

BRONCKART, Jean-Paul. Atividade de linguagem, textos e discursos: por um interacionismo sócio-discursivo. São Paulo: Educ, 1999.

CANDIDO, Evelyn Coutinho Rother; GOMES, Nataniel dos Santos. Memes: uma linguagem lúdica. Philologus, Rio de Janeiro, ano 21, n. 63, p. 1293-1303, set./dez., 2015.

\footnotetext{
${ }^{7}$ No original: "As the use made of co-deployed and interlinked visual modalities increases, however, the question must be raised as to whether we can afford to continue relying on implicit learning by 'osmosis' for multimodality".
} 


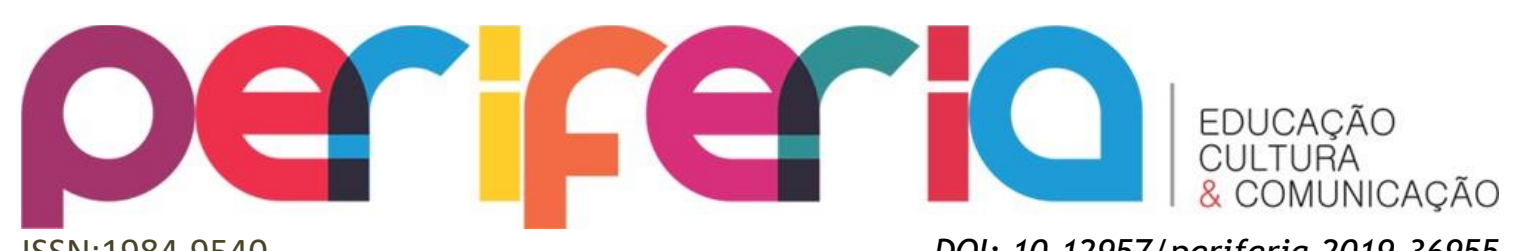

ISSN:1984-9540

CHEN, Carl. The creation and meaning of internet memes in 4chan: popular internet culture in the age of online digital reproduction. Habitus, New Haven, v. 3, p. 6-19. 2012. Disponível em:

<http://citeseerx. ist.psu.edu/viewdoc/download?doi=10.1.1.363.7029\&rep=rep1\&t ype=pdf\#page=6>. Acesso em: 29 ago. 2018.

COPE, Bill; KALANTZIS, Mary. A grammar of multimodality. International Journal of Learning, Champaign, v. 16, n. 2, pp. 361-427, 2009.

FAIRCLOUGH, Norman. Discourse and social change. Cambridge, UK:

Polity/Blackwell, 1992.

HALLIDAY, Michael. Language as social semiotic: towards a general sociolinguistic theory. In: MAKKAI, Adam; MAKKAI, Valerie Becker (Eds.). The first lacus forum. Californian: Hornbeam, 1975. p. 17-46.

HASAN, Ruqaiya. Situation and the definition of genres. In: GRIMSHSW A D. (Org.). What's going on here? Complementary studies of professional talk. Norwood: Ablex, 1994. p. 127-72. (The Multiple Analysis Project, 2).

HIIPPALA, Tuomo. Multimodal genre analysis. In: NORRIS, Sigrid; MAIER, Carmen Daniela (Eds.). Texts, images, and interactions: a reader in multimodality. Berlin: De Gruyter, 2014. p. 111-123.

HOUAISS, Antônio. Dicionário eletrônico Houaiss da língua portuguesa. Rio de Janeiro: Objetiva, 2009.

JEWITT, Carey. Multimodal methods for researching digital technologies. In: PRICE, Sara; JEWITT, Carey; BROWN, Barry (Eds.). The Sage handbook of digital technology research. Thousand Oaks: Sage, 2013. p. 250-265.

JOLY, Martine. Introdução à análise da imagem. Campinas: Papirus, 1996.

KNOBEL, Michele; LANKSHEAR, Colin. Online memes, affinities, and cultural production. In: A new literacies sampler. New York: Peter Lang, 2007. p. 199-227.

KRESS, Gunther. Ideological structures in discourse. In: VAN DIJK, Teun A. (Ed.). Handbook of discourse analysis. Orlando: Academic, 1985. p. 27-42.

Multimodality: a social semiotic approach to contemporary communication. New London: Routledge, 2009.

KRESS, Gunther; VAN LEEUWEN, Theo. Reading images: the grammar of visual design. London: Psychology, 1996.

MARTINO, Luís Mauro Sá. Teoria das mídias digitais: linguagens, ambientes e redes. 2. ed. Petrópolis: Vozes, 2015. 


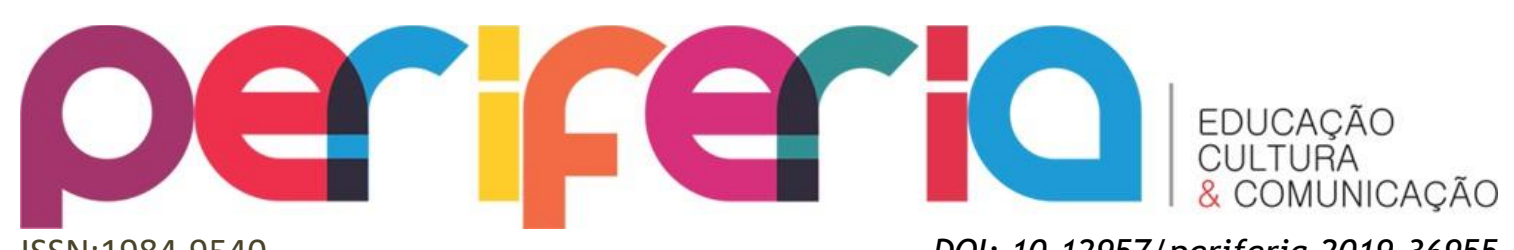

MILLER, Carolyn R. Genre as social action. In: FREEDMAN, A. MEDWAY, P. (Eds.). Genre and new rethoric. London: Taylor \& Francis, 1994. p. 23-42. - Gênero como ação social. Estudos sobre: gênero textual, agência e tecnologia. Recife: Ed. Universitária da UFPE, p. 21-44, 2009.

RAJAGOPALAN, Kanavillil. Como o internetês desafia a linguística. In: SHEPHERD, Tania G.; ALIÉS, Tânia G. (Orgs.). Linguística da internet. São Paulo: Contexto, 2013. p. 37-53.

ROSE, Gillian. Visual methodologies: an introduction to researching with visual materials. Thousand Oaks: Sage, 2016.

SHIFMAN, Limor. Memes in a digital world: reconciling with a conceptual troublemaker. Journal of Computer-Mediated Communication, State College, PA, v. 18, n. 3, p. 362-377, 2013.

SWALES, John Malcolm. Re-thinking genre: another look at discourse community effects. In: RETHINKING GENRE COLLOQUIUM. 1992, Otawa. Proceedings... Otawa: Carleton University, 1992.

TODOROV, Tzvetan. The origin of genres. New Literary History, Baltimore, v. 8, n. 1, p. 159-170, 1976. 